\title{
Obtaining Factors Affecting Innovative Work Behavior (IWB) of a Local Bank Employees under Islamic Leadership: Application of Partial Least Squares Method
}

\author{
Achmad Sani Supriyanto* \\ State Islamic University of Maulana Malik Ibrahim Malang, Indonesia
}

(Received: May 29, 2019 / Revised: June 16, 2019 / Accepted: June 19, 2019)

\begin{abstract}
This study aims were: 1) to know the direct effect of Islamic Leadership on Islamic Performance, 2) to know the direct effect of Empowerment on Innovative Work Behavior, 3) to test the role of Empowerment as mediation the effect of Islamic Leadership on Islamic Performance, 4) to test the role of Innovative Work Behavior as mediation the effect of Islamic Leadership on Islamic Performance. The population was all employees of Bank Jatim Syariah at Surabaya Center Office. It was consisted of Bank Jatim Syariah at Surabaya Branch Office and Kediri Branch Office. Samples were selected by proportional random sampling and data was analyzed by PLS (Partial Least Square). The study had four findings. First, Islamic Leadership has a significant effect on Islamic Performance. Second, Empowerment has a significant effect on Innovative Work Behavior. Third, Empowerment mediates the effect of Islamic Leadership on Islamic Performance. This condition illustrates that employees must be empowered and involved in all organizational processes to improve performance. Forth, Innovative Work Behavior cannot mediate the effect of Islamic Leadership on Islamic Performance. Innovative Work Behavior arises from the individual. It was the individuals desire to introduce their ideas to a group or organization where they work.
\end{abstract}

Keywords: Empowerment, Innovative Work Behavior, Organizational Efficiency, Islamic Leadership, Partial Least Squares Regression, Proportional Random Sampling

* Corresponding Author, E-mail: achmad_sani72@yahoo.com

\section{INTRODUCTION}

Leadership has become the research object for long time. It was based on various leadership advance in organizations. Therefore, leadership practice has continued to develop from the past to present and will certainly continue to develop in future.

Leadership was analyzed as one of most complicated social processes (Fry and Kriger, 2009). Leaders give di- rection to followers, set goals, then motivate subordinates to work, utilize their business together in same direction. Therefore, leaders can get the desired organizational goals and minimize the gap between the achieved goals and desired goals (Sani et al., 2018; Novikova et al., 2018).

\subsection{Literature Review}

Global economy creates full competition in all in- 
dustries. It was important to have the right managerial skills in an organization. This was evident with the majority companies investing in leadership programs due to various challenges at their leadership level (Olutade et al., 2015; Maurice, 2013; Chidoko and Mashavira, 2014; Yuliansyah, 2015; Kadasala et al., 2016; Abiodun, 2014; Sabri and Sweis, 2015; Elkhayat and ElBannan, 2018; Jenaabad and Mostafaei 2014; Forgha et al., 2018). Gentry et al. (2014) identified six possible leadership challenges namely: developing managerial effectiveness; inspire others; develop employees; lead team; guiding change and managing internal and political stakeholders.

Several studies on spiritual leadership have been carried out (Fry, 2003; Duchon and Plowman, 2005) to show that spiritual leadership affects on productivity and organizational performance. Daud et al. (2007) stated that quality of Islamic Leadership can improve employee performance. Milliman et al. (2003) stated that leadership correlates with job satisfaction, work involvement, organizational commitment, employee involvement. Leadership has the desired impact on job satisfaction, communication and perceptions of work environment (Morrow, 1997). Thus, leadership success was highly dependent on motivation, skills, commitment, and extra behavior roles of people involved in an organization (Guimaraes, 1997). Whereas Elbaz and Haddoud (2017) states that spiritual leadership has no effect on performance but through job satisfaction.

Many leadership researches has been done but rarely review the religious perspective (Kamil et al., 2011). Islamic Leadership was very important to increase organizational effectiveness, but in reality there were still differences between theory and practice (Ather and Sobbani, 2007; Nze et al., 2016; Hang et al., 2016; Owusu-Antwi et al., 2017; Ahmed et al., 2018; Dinesh et al., 2017; Obodo, 2018). The empirical tests of spiritual leadership in relation with Empowerment and Innovative Work Behavior were still rarely done.

Many of previous studies on banking leadership examined transformative and transactional leadership styles (Bass et al., 2003). Islamic banking should be a competitive banking environment and become a strong partner for conventional banking. It needs to rely on their employees as an intermediary between the banking sector and customers to achieve a large market share. Therefore, banks must strive to create positive attitudes from employees, motivating employees to be more committed, empowering employees. It ultimately should have positive contribution on organization. One way to do was to develop Innovative Work Behavior (IWB). This behavior describes the added value of employees as one form of prosocial behavior, namely positive, constructive and meaningful social behavior. IWB could change the formal atmosphere of organization to become more relax, full cooperation, reduce the tension of employees to create a supportive atmosphere to increase employee productivity. It would have an impact to achieve organizational effectiveness and efficiency (Purmamisari, 2012). IWB can improve organizational efficiency (Podsakoff et al., 2009; Chiang and Tsung, 2012; Gumel, 2017); performance (Dorner, 2016). Organ et al. (2005) stated that without employee involvement, organization will become a fragile social system and will be crushed by competition. Employee involvement was demonstrated through acceptance and strong belief in values and organization goals (Ali and Haseeb, 2019; Haseeb et al., 2018; Haseeb et al., 2019; Suryanto et al., 2018; Farzadnia et al., 2017).

The study to examine relationship between leadership and IWB were still limited and having contradictions. This study seeks to explain leadership from an Islamic perspective, proposing a framework for Islamic Leadership with Empowerment and IWB mediation using the model from Dorner (2016), Alkhodary (2016) and previous empirical studies. This was intended to integrate spirituality leadership, empowerment and IWB in a model that can be used by researchers to better understand IWB. This model should add to scarcity of literature regarding the relation of spirituality and Islamic Performance through Empowerment and IWB. This will help the organization to understand the leadership role to increase employee IWB which ultimately will improve organizational performance.

\subsection{Theoretical Review}

\subsubsection{Relations of Islamic Leadership and Islamic Performance.}

Islamic Leadership was based on concept of Prophet Muhammad. This leadership offers a leadership model to develop a strategy to achieve success in a balanced manner in business, family, social and spiritual, based on example of leadership and management of Prophet $\mathrm{Mu}-$ hammad and spirit of Asmaul Husna (Syafi'i, 2010).

Hakim (2012) stated that Islamic Leadership can improve Islamic Performance. Islamic Performance was the manifestation of someone work who not only orient to the world but also hereafter. The performance was always based on Islamic values. Islamic Performance was manifested in a balance of life between the world and hereafter, working hard, doing the work as well as possible and giving some portion of income to others who need it (Hakim, 2012).

Daud et al. (2007) stated that quality of Islamic Leadership could improve employee performance. Wijayanti and Wajni (2012) examined the effect of Islamic Leadership, motivation and job satisfaction on employee performance. The results showed that Islamic Leadership had a significant positive effect on employee performance. Based on empirical studies, research hypothesis was: 
H1: Islamic Leadership affects on Islamic Performance.

\subsubsection{Relations of Empowerment and Innovative Work Behavior}

Empowerment was defined as the extent of employees' involvement in a company in various management activities. Participation in management activities give employees new knowledge, more disciplined, involved in decision-making process, and have the opportunity to solve problems faced by organizations (Juran and Gryna, 1993). Employee participation was exemplified by teamwork, involvement in organizational activities and employee commitment (Zhang, 2000).

IWB was a behavior with aim to introduce new ideas, use new ideas as a set of tools for organizational progress (De Jong and Den Hartog, 2007). Axtell et al. (2000) define Innovative Work Behavior as the capability improvement in new ideas relating to the jobs within organization.

Empowerment has relations with Innovative Work Behavior. Alkhodary (2016) showed the relationship between Empowerment and IWB (originality, ideas, sensitivity to problems). Based on empirical studies, research hypothesis was:

H2: Empowerment affects on the Innovative Work Behavior.

\subsubsection{The Effect of Islamic Leadership on Islamic Performance Mediated by Empowerment.}

Leadership in Islam view was a mandate and responsibility that was not only accountable to members they lead, but also will be accountable before Allah SWT (Hakim, 2012). Islamic Performance was the manifestation of someone work who was not only oriented to world but also hereafter. Islamic Performance was manifested in five indicators, namely quantity, accuracy in work, quality, willingness to help others, and charity (Hakim, 2012).

Empowerment was a process to encourage organiza- tional members individually and collectively to make decisions to affect their work environment (Ivancevich et al., 2006). Theory of $\mathrm{X}$ and $\mathrm{Y}$ explained a very important role between individuals and managers. Managers play a role to improve performance through individual Empowerment practices (Bourini et al., 2018). Based on empirical and theoretical studies, research hypothesis was:

H3: Empowerment mediates the effect of Islamic Leadership on Islamic Performance.

\subsubsection{The Effect of Islamic Leadership on Islamic Performance Mediated by Innovative Work Behavior}

West and Farr (1990) defined Innovative Work Behavior (IWB) as a behavior with aim to introduce and implement new ideas into work in order to improve performance. Islamic Performance was the manifestation of someone work oriented to world and also afterlife (Hakim, 2012).

The relationship between Islamic Leadership, Innovative Work Behavior and Islamic Performance was shown De Jong and Den Hartog (2007) that leaders affect employees' innovative behavior through deliberate actions aimed to stimulate behavior that was manifested in application of new ideas to support performance. Dorner (2016) examined IWB in relation to employee expectations and employee performance. The results showed that IWB could improve employee performance; and but did not affect employees' expectations. Based on empirical studies, the research hypothesis was:

H4: Innovative Work Behavior mediate the effect of Islamic Leadership on Islamic Performance.

\subsection{Hypotheses Model}

The hypotheses model of this research is shown in Figure 1.

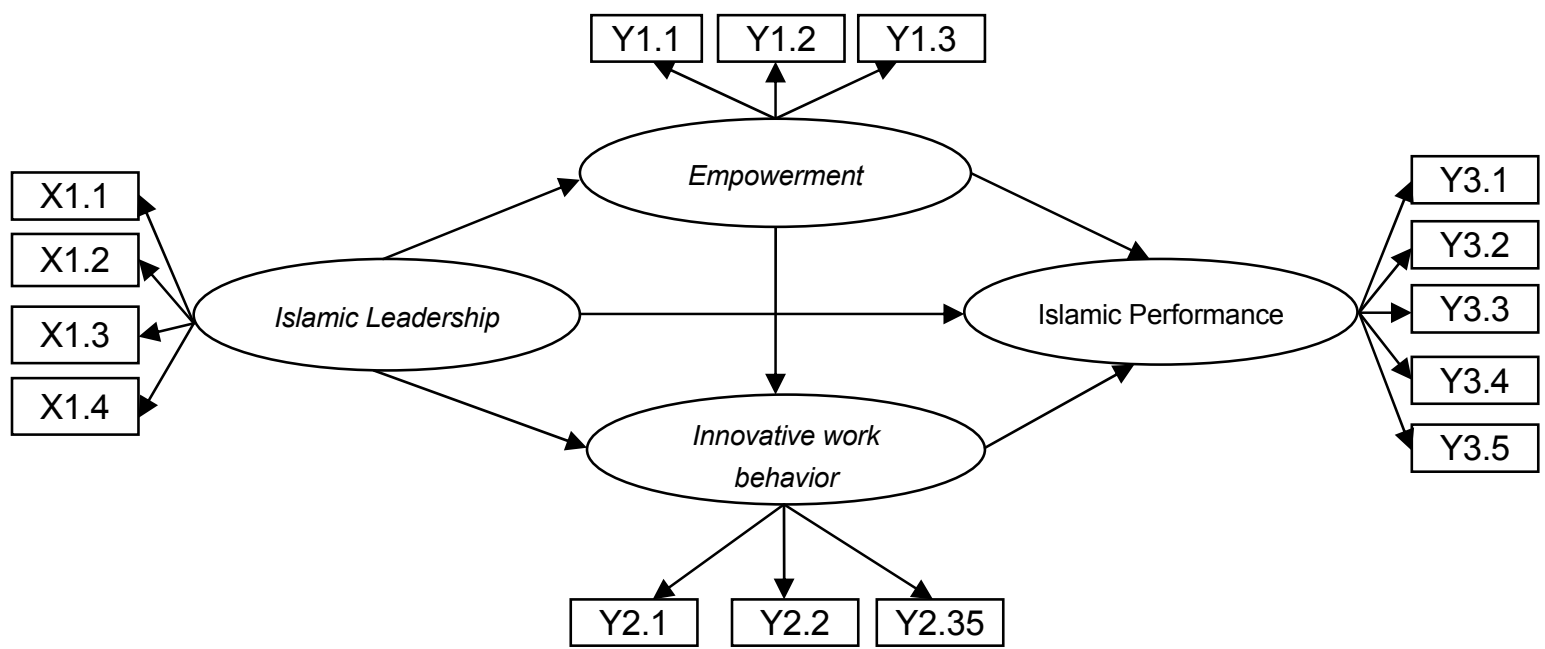

Figure 1. The effect of islamic leadership, empowerment, innovative work behavior on islamic performance. 


\section{METHODOLOGY}

The population was all employees of Bank Jatim Syariah at Surabaya Center Office, totalling employees. The samples were selected by Slovin formula at $7 \%$ precision, Samples in this study were all permanent employees including leadership elements who have a minimum work period of 1 year at Bank Jatim Syariah at Surabaya Center Office, totalling 115 employees. Data was collected by questionnaires, measured with five-point Likert scales.

\subsection{Data Analysis Techniques}

Descriptive statistical analysis was used to determine the frequency distribution of respondents' answers from questionnaire and to describe in depth the studied variables. Data was analyzed by Partial Least Square (PLS). This model was developed as an alternative to situations where the weak theoretical basis to design a model and / or the available indicators did not meet the reflective measurement model (Solimun, 2012). Mediation testing with a procedure developed by Sobel known as the Sobel test (Sobel test) using Free Statistic Calculation for Sobel Test version 4.0.

\section{RESEARCH RESULTS}

The Goodness of Fit testing of structural model for inner model uses predictive-relevance (Q2) to measure the observation value generated by the model. The Q2 has a magnitude range values of $0<\mathrm{Q} 2<1$, closer to 1 means the model was better. The results of Goodness of Fit Test is shown in Table 1.

The calculation results show a predictive-relevance value of 0.7841 or $78.41 \%$. It indicates that diversity of data that can be explained by the model at $78.41 \%$, in other words the $78.41 \%$ information content in data can be explained by the model. The remaining $21.59 \%$ was explained by other variables outside the model and errors. It means the PLS model was good, because it can explain $78.41 \%$ of overall information.

\subsection{Hypotheses Testing (Inner Model)}

Hypotheses test for inner model is shown in Table 2.

The hypothesis testing for the direct effect can be seen in Figure 2.

Table 1. Goodness of fit test results

\begin{tabular}{clc}
\hline Structural Model & \multicolumn{1}{c}{ Endogenous Variables } & R - Square \\
\hline 1 & Empowerment (Y1) & 0.491 \\
\hline 2 & Innovative work Behavior (Y2) & 0.270 \\
\hline 3 & Islamic Performance (Y3) & 0.419 \\
\hline
\end{tabular}

Table 2. Hypothesis testing for the direct effect

\begin{tabular}{llcccc}
\hline \multicolumn{1}{c}{ Independent Variables } & \multicolumn{1}{c}{ Dependent Variables } & Path Coefficients & t statistic & p-value & Description \\
\hline Empowerment & Innovative Work Behavior & 0.442 & 3.506 & 0.000 & Significant \\
\hline Empowerment & Islamic Performance & 0.281 & 2.056 & 0.042 & Significant \\
\hline Islamic Leadership & Empowerment & 0.539 & 9.116 & 0.000 & Significant \\
\hline Islamic Leadership & Innovative Work Behavior & 0.062 & 0.577 & 0.565 & Insignificant \\
\hline Islamic Leadership & Islamic Performance & 0.268 & 2.405 & 0.000 & Significant \\
\hline Innovative Work Behavior & Islamic Performance & 0.043 & 0.382 & 0.703 & Insignificant \\
\hline
\end{tabular}

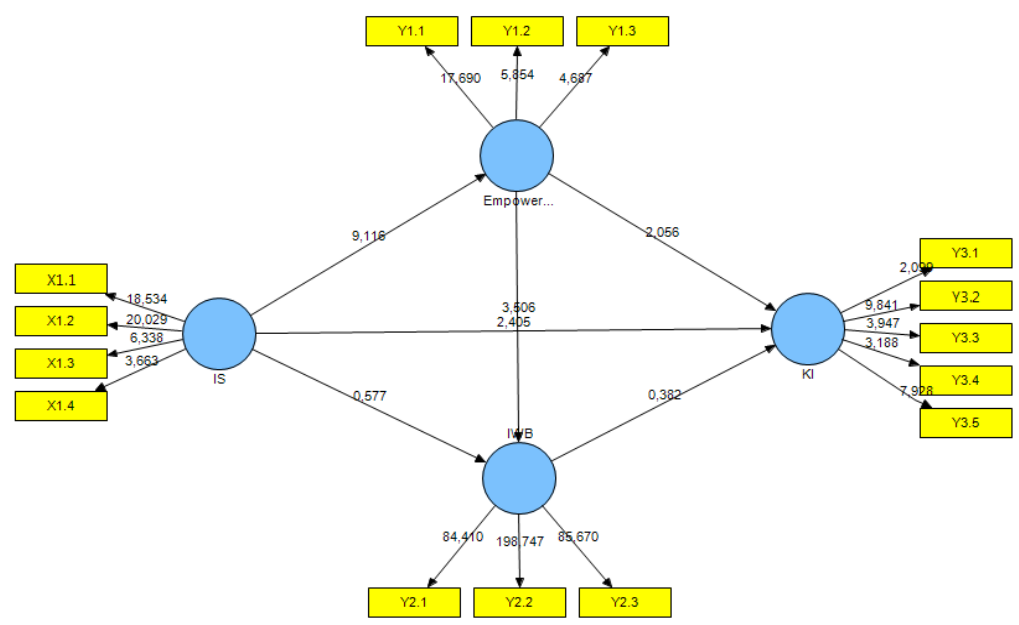

Figure 2. Path diagram of structural model in PLS. 
Obtaining Factors Affecting Innovative Work Behavior (IWB) of a Local Bank Employees under Islamic Leadership

Vol 18, No 3, September 2019, pp.417-425, (C) 2019 KIIE

Table 3. The results of sobel test analysis

\begin{tabular}{ccccccccr}
\hline Path & A & B & SEA & SEB & t count & sig & Description \\
\hline IS-EMP-KI & 0.539 & 0.268 & 0.059 & 0.112 & 2.315 & 0.020 & Sig \\
\hline IS-IWB-KI & 0.061 & 0.043 & 0.107 & 0.113 & 0.316 & 0.752 & Non sig \\
\hline
\end{tabular}

\subsection{Hypothesis Testing and Coefficients of Mediation Path}

The mediation hypothesis test was needed to detect the position of intervening variable in the model. Testing can be done with a procedure developed by Sobel and was known as the Sobel test (Sobel Test). The Sobel test was done by examining the effect of Islamic Leadership on Islamic Performance through Empowerment and Innovative Work Behavior. The Sobel test was done by free Sobel test calculator for the significance of mediation version 4.0. Table 3 shows the results of Sobel Test analysis.

Sobel test showed that the relationship of Islamic Leadership, Empowerment and Islamic Performance has value of $2.315>1.96$ and significance of $0.020<0.05$. It means that Empowerment mediates the effect of Islamic Leadership on Islamic Performance. The test results showed the $t$ count $>\mathrm{t}$ table and sig $<0.05$; so Empowerment mediates the effect of Islamic Leadership on Islamic Performance.

Sobel test showed that the relationship of Islamic Leadership, Innovative Work Behavior and Islamic Performance has value of $0.316<1.96$ and significance was $0.752>0.05$. It means Innovative Work Behavior does not mediate the effect of Islamic Leadership on Islamic Performance. The test results show $\mathrm{t}$ count $<\mathrm{t}$ table and sig $>$ 0.05 ; so, the Innovative Work Behavior does not mediate the effect of Islamic Leadership on Islamic Performance.

\section{DISCUSSION}

\subsection{Effect of Islamic Leadership on Islamic Performance}

Inner model path analysis showed that Islamic Leadership has a significant effect on Islamic Performance. It was consistent with Fry (2003) that spiritual leadership affects on productivity and organizational performance. It was also consistent with the findings of Duchon and Plowman (2005) that spiritual leadership affects on performance. The study results also consistent with the Gadenne and Sharma (2009) that performance was affected by TQM Practices. Soft TQM practices contribute to performance, these include leadership, training and supplier relations. Hard TQM practices contribute to performance. These include continuous improvement, benchmarking, increased efficiency, and quality measurement.
The research results also support the research results of Daud et al. (2007) that quality of Islamic Leadership could improve employee performance. Wijayanti and Wajni (2012) also supported that Islamic Leadership has a significant positive effect on employee performance. Adversely, the study results inconsistent with Whereas Elbaz and Haddoud (2017) that spiritual leadership has no effect on performance.

The research results support the opinion of Maharani (2017) that leadership patterns were considered successful when guided by corporate culture of five akhlaqul karimah (good morality) attitudes. The application of most ideal and appropriate Islamic Leadership style was a leadership style to include attitudes of akhlaqul karimah, namely shidiq, istiqamah, fathonah, amanah, and tabligh (Maharani, 2017; Mulyono et al., 2018).

Leaders who adopt a spiritual leadership style will create a spiritual work environment. It generates benefits not only for individuals but also for organization. Spiritual leadership creates positive effects on employees, especially comfort, psychological impact, increased organizational commitment, increased productivity and even organizational performance (Fry, 2003; Martins et al., 2018).

\subsection{Effect of Empowerment on Innovative Work Behavior}

The path analysis result for inner model shows that Empowerment has a significant effect on Innovative Work Behavior. It is consistent with Alkhodary (2016) who examines the effect of Empowerment on IWB. The results showed that Empowerment has significant relationship on Innovative Work Behavior. The study results also supported the opinion of Organ et al. (2005) that without employee involvement, organization will become a fragile social system and will be crushed by competition. Employee involvement was demonstrated through the attitude of acceptance, strong belief in values and goals of organization.

Empowerment was defined as the employee involvement level in a company in various management activities. Participation in management activities give employees new knowledge, more disciplined, involved in decision-making process, and have the opportunity to solve problems faced by organizations (Juran and Gryna, 1993). Employee participation was exemplified by teamwork, involvement in organizational activities and employee commitment (Zhang, 2000; Muhammad, 2018).

Robbins (2006) defines employee involvement as a 
participation process that uses all employee capacities designed to increase commitment to organizational success. Involving employees in making decisions process can increase autonomy and control over their working lives, employees will be more motivated and more committed to organization, and more productive.

IWB was a behavior with aim to introduce new ideas, use new ideas as a set of tools for organizational progress (De Jong and Den Hartog, 2007). Axtell et al. (2000) defined Innovative Work Behavior as higher capacity for a number of new ideas relating to a number of jobs within organization. IWB was not only triggered by high motivation, but can be part of a strategy to reduce the negative effects of high job design (Janssen, 2000). Therefore, IWB arises as a result of employee involvement for challenging jobs. On other hand, they were also involved in innovation strategies when they have low motivation and high pressure. The combination of high work levels and low leadership control, varied work designs require employees to behave innovatively through work involvement.

\subsection{Empowerment as Mediation the Effect of Islamic Leadership on Islamic Performance}

The path analysis result for inner model shows that Islamic Leadership has a significant affect on Empowerment. Empowerment also affects on Islamic Performance. These study results complement the research of Wijayanti and Wajni (2012) that Islamic Leadership has a significant positive effect on employee performance. These study results support Hakim (2012) that Islamic Leadership could improve Islamic Performance. These study results also Bari et al. (2016) that soft TQM viewed from leadership affects on employee performance through psychological contracts.

The field research results also support Bourini et al. (2018) that there was a very important role between individuals and managers, where managers have a role to improve performance through individual empowerment practices. This condition illustrates that a leader was not only required to set a good example, but also must have an awareness that subordinates were valuable. They must be empowered and involved in all organizational processes.

\subsection{Innovative Work Behavior as Mediation the Effect of Islamic Leadership on Islamic Performance.}

The path analysis result for inner model shows that Islamic Leadership does not have a significant effect on Innovative Work Behavior. Likewise, Innovative Work Behavior does not affect on Islamic Performance. Because the two paths were not significant, it can be concluded that Innovative Work Behavior was not a media- tion the effect of Islamic Leadership on Islamic Performance. These study results inconsistent with Elbaz and Haddoud (2017) study that spiritual leadership affect on performance with job satisfaction as mediation variable.

Innovative Work Behavior cannot mediate the effect of Islamic Leadership on Islamic Performance, because innovation emphasizes creativity and implementation of ideas to improve performance. Furthermore, Innovative Work Behavior is explained as individual behavior with aim to achieve intentional initiation and recognition (in role of work, group or organization) regarding ideas, processes and products. The IWB was developed to encourage creative ideas. Purba (2009) suggests that innovative behavior emphasizes on the existence of a creative attitude, there was a process to change attitudes from traditional to modern, or from not progressed to an advanced attitude.

Leadership did not affect on Innovative Work Behavior because this behavior arises from the individual to introduce ideas to a group or organization where they work. Janssen (2000) said that Innovative Work Behavior consists of idea generation, it refers to development and usage of ideas that very useful for company

Innovative Work Behavior arises when employees were respected, they were willing to reciprocate with higher innovative behavior, whereas when they see their work was less valued, they tend to limit the IWB. Based on social exchange theory, it can be concluded that managerial behavior has an effect on employee behavior. De Jong and Den Hartog (2007) stated that employees vary in how to do work or show their IWB. Every employee always innovates to do his job properly. And when their performance was considered good, they don't need IWB behavior anymore.

\subsection{Contribution}

These research results accommodate two previous studies. Alkhodary (2016) found that Empowerment had an effect on IWB. While Dorner (2016) stated that quality of Islamic Leadership could improve employee performance. These research results combine the research of Dorner (2016) and Alkhodary (2016) that quality of Islamic Leadership could improve employee performance when employees engage in innovative behavior moderated by Empowerment.

These research results show several factors that can improve Islamic Performance, including leadership, empowerment and innovative behavior of employees. The managerial parties should increase these three factors in order to improve employee performance.

The empirical evidence shows a need for management to apply Islamic values in daily activities. The application of Islamic values must be supported by both leaders and employees. Leaders determine the right poli- 
cies relating to implementation of Islamic values, while employees were required to participate in implementation of Islamic values.

\section{CONCLUSION}

Islamic Leadership has a significant effect on Islamic Performance. The leadership practice will create the mindset for subordinates to always responsible to their work, always carry out the mandate in their work activities. The stronger Islamic Leadership can increase Innovative Work Behavior.

Empowerment has a direct effect on Innovative Work Behavior. Without employee involvement, organization will become a fragile social system and will be crushed by competition. Employee involvement was demonstrated by the attitude of acceptance, strong belief in values and goals of organization.

Empowerment mediates the effect of Islamic Leadership on Islamic Performance. This condition illustrates that a leader was not only required to set a good example, but also must have an awareness that employees were valuable. They must be empowered and involved in all organizational processes to improve performance.

Innovative Work Behavior was not mediation the effect of Islamic Leadership on Islamic Performance, because innovation places more emphasis on creativity and implementation of ideas. Innovative Work Behavior arises from the individual to introduce ideas he made to a group or organization where they work.

\subsection{Limitations}

This study design still cannot completely eliminate the possibility of a common method bias because all the data was collected by self-reports of respondents. Differences in managerial scores between managers and employees can also cause bias. Future research should recommend managers to provide an assessment to employees. It can be used as cross checks of employee data with leaders.

\section{REFERENCES}

Abiodun, B. Y. (2014), The prospects of accounting and economic systems in the era of global knowledge economy, The Economics and Finance Letters, 1(2), 9-14.

Ahmed, A., Rehan, R., Chhapra, I. U., and Supro, S. (2018), Interest rate and financial performance of banks in Pakistan, International Journal of Applied Economics, Finance and Accounting, 2(1), 1-7.

Ali, A. and Haseeb, M. (2019), Radio frequency identification
(RFID) technology as a strategic tool towards higher performance of supply chain operations in textile and apparel industry of Malaysia, Uncertain Supply Chain Management, 7(2), 215-226.

Alkhodary, D. (2016), The relationship between employee's empowerment and innovative work behavior, International Journal of Managerial Studies and Research (IJMSR), 4(2), 1-15.

Ather, S. M and Sobhani, F. A. (2007), Managerial leadership: An islamic perspective, IIUC Studies, 4, 7-24.

Axtell, C. M., Holman, D. J., Unsworth, K. L., and Wall, T. D. (2000), Shopfloor inovation faciliting the sugesstion and implementation of ideas, Journal Of Occupational and Organizational Psychology, 73(3), 265-285.

Bari, M. W., Fanchen, M., and Baloch, M. A. (2016), TQM soft practices and job satisfaction: Mediating role of relational psychological contract, ProcediaSocial and Behavioral Sciences, 235, 453-462.

Bass, B. M., Avolio, B. J., Jung, D. I., and Berson, Y. (2003), Predicting unit performance by assessing transformational and transactional leadership, Journal of Applied Psychology, 88(2), 207-218.

Bourini, I., Jahmani, A., Mumtaz, R., and Al-Bourini, F. (2018), Investigating the managerial practices' effect employee-perceived service quality with the moderating role of supportive leadership behavior, European Research on Management and Business Economics, 25(1), 8-14.

Chiang, F. C. and Tsung, S. H. (2012), The impacts of perceived organizational support and psychological empowerment on the job performance: The mediating effects of organizational citizenship behavior, International Journal of Hospitality Management, 31(1), 180-190.

Chidoko, C. and Mashavira, N. (2014), An analysis of corporate governance in the banking sector of Zimbabwe, Humanities and Social Sciences Letters, 2(3), 174180.

Daud, W. N., Rahim, M. A., and Nasrudin, A. M. (2007), Quality of islamic leadership and organizational performance within the Takaful industry in Malaysia: A conceptual study, Asian Social Science, 10(21),135144.

De Jong, J. P. J. and Den Hartog, D. N. (2007), How leaders influence employees' innovative behavior, European Journal of Innovation Management, 10(1), 41-64.

Dinesh, K. K., Abubacker, K. M., and Babu, V. S. (2017), Implementation and study on innovative new teaching methods to enhance learning of mechanical principles module at undergraduate level, Humanities \& Social Sciences Reviews, 5(2), 141-148.

Dorner, N. (2016), Innovative work behavior: The role of employee expectations and effects on job performance, 
Ph.D. dissertation, University of St. Gallen.

Duchon, D. and Plowman, D. A. (2005), Nurturing the spirit at work: Impact on unit performance, The Leadership Quarterly, 16(5), 807-833.

Elbaz, M. A. and Haddoud, M. Y. (2017), The role of wisdom leadership in increasing job performance: Evidence from the Egyptian tourism sector, Tourism Management, 63, 66-76.

Elkhayat, N. and ElBannan, M. A. (2018), State divestitures and bank performance: Empirical evidence from the middle east and north africa region, Asian Economic and Financial Review, 8(2), 145-171.

Farzadnia, E., Hosseini, Z., and Riahi, A. (2017), Study of hospital quality management and improvement rates in the hospitals, Journal of Humanities Insights, 01(01), 7-11.

Forgha, G., Serge, T., and Ajong, N. (2018), Effects of lending relationship on the interest rates of commercial banks in Cameroon, Asian Journal of Economic Modelling, 6(2), 208-219.

Fry, L. and Kriger, M. (2009), Towards a theory of beingcentered leadership: Multiple levels of being as context for effective leadership, Human Relations, 62(11), 1667-1696.

Fry, L. W. (2003), Toward a theory of spiritual leadership, The Leadership quarterly, 14(6), 693-727.

Gadenne, D. and Sharma, B. (2009), An investigation of the hard and soft quality management factors of Australian SMEs and their association with firm performance, International Journal of Quality \& Reliability Management, 26(9), 865-880.

Gentry, W. A., Eckert, R. H., Munusamy, V. P., Stawiski, S. A., Martin, J. L. (2014), The needs of participants in leadership development programs: A qualitative and quantitative cross-country investigation, Journal of Leadership \& Organizational Studies, 21(1), 83101.

Guimaraes, T. (1997), Assessing employee turnover intentions before/after TQM, International Journal of Quality \& Reliability Management, 14(1), 46-63.

Gumel, F. (2017), The effects of European Negotiatory state of Turkey on local management, Journal of Humanities Insights, 1(2), 57-62.

Hakim, A. (2012), The implementation of islamic leadership and islamic organizational culture and its influence on islamic working motivation and islamic performance PT bank Mu'amalat Indonesia Tbk, Employee in the Central Java. Asia Pacific Management Review, 17(1), 77-90.

Hang, H. T. T., Vy, P. D., and Bandaralage, J. (2016), Mergers, acquisitions and market concentration in the banking sector: The case of Vietnam, Asian Journal of Economics and Empirical Research, 3(1), 49-58.

Haseeb, M., Abidin, I. S. Z., Hye, Q. M. A., and Hartani,
N. H. (2018), The impact of renewable energy on economic well-being of Malaysia: Fresh evidence from auto regressive distributed lag bound testing approach, International Journal of Energy Economics and Policy, 9(1), 269-275.

Haseeb, M., Zandi, G., Hartani, N. H., Pahi, M. H., and Nadeem, S. (2019), Environmental analysis of the effect of population growth rate on supply chain performance and economic growth of Indonesia, Ekoloji, 28(107), 417-426.

Ivancevich, J. M., Konopaske, R., and Matteson, M. T. (2006), Perilaku Dan Manajemen Organisasi (7th ed.), Erlangga, Jakarta.

Janssen, O. (2000), Job demands, perceptions of effortreward fairness, and innovative work behaviorm Journal of Occupational and Organizational Psycholog, 73(3), 287-302.

Jenaabadi, H. and Mostafaei, H. (2014), Investigate the relationship between the components of emotional intelligence and aggression of high school male students, UCT Journal of Social Sciences and Humanities Research, 2(1), 25-28.

Juran, J. M. and Gryna, F. M. (1993), Quality Planning and Analysis (3rd ed.), McGraw-Hill, Inc., New York.

Kadasala, N. R., Narayanan, B., and Liu, Y. (2016), International trade regulations on BPA: Global health and economic implications, Asian Development Policy Review, 4(4), 134-142.

Kamil, N. M., Ali Hussain, M S., and Sulaiman, M. B. (2011), The components of spirituality in the business organizational context: The case of Malaysia, Asian Journal of Business and Management Sciences , 1(2), 166-180.

Maharani, V. (2017), The Effect Of Transformational Leadership On Organizational Citizenship Behavior Mediated By Job Satisfaction and Organizational Commitment, Dr. dissertation, Brawijaya University, Malang, Indonesia.

Martins, V. F., Sampaio, P. N. M., Cordeiro, A. J. A., and Viana, B. F. (2018), Implementing a data network infrastructure course using a problem-based learning methodology, Journal of Information Systems Engineering \& Management, $3(2), 10$.

Maurice, I. U. (2013), Impact of product development and innovation on organisational performance, International Journal of Management and Sustainability, 2(12), 220-230.

Milliman, J., Czaplewski, A., and Ferguson, J. (2003), Workplace spirituality and employee work attitudes: An exploratory empirical assessment, Journal of Organizational Change Management, 16(4), 426447.

Morrow, P. C. (1997), The measurement of TQM principles and work-related outcomes, Journal of Organizational Behavior, 18(4), 363-376. 
Muhammad, K. (2018), The effects of electronic human resource management on financial institutes, Journal of Humanities Insights, $02(01), 1-5$.

Mulyono, D., Asmawi, M., and Nuriah, T. (2018), The effect of reciprocal teaching, student facilitator and explaining and learning independence on mathematical learning results by controlling the initial ability of students, International Electronic Journal of Mathematics Education, 13(3), 199-205.

Novikova, I. N., Popova, L. G., Shatilova, L. M., Biryukova, E. V., Guseva, A. E., and Khukhuni, G. T. (2018), Lexical and semantic representation of the linguistic and cultural concept "Rest" in the English, German, and Russian languages, Opción, 34(85-2), 237-256.

Nze, I. C., Ogwude, I. C., Nnadi, K. U., and Ibe, C. C. (2016), Modelling the relationship between demand for river port services and vessel supply costs: Empirical evidence from Nigeria, Global Journal of Social Sciences Studies, 2(3), 144-149.

Obodo, N. A. (2018), Content analysis of time management as a tool for corporate effectiveness, International Journal of Applied Economics, Finance and Accounting, 2(2), 36-39.

Olutade, M., Liefooghe, A., and Olakunle, A. O. (2015), Influence of entrepreneurial leadership skills on employees' motivation and job satisfaction: A leader member exchange (LMX) approach, International Journal of Academic Research In Business and Social Sciences, 5(9), 188-214

Organ, D. W., Podsakoff, P. M., and MacKenzie, S. B. (2005), Organizational citizenship Behavior: Its Nature, Antecedents and Consequences (1st ed.), SAGE Publications, Thousand Oaks.

Owusu-Antwi, G., Banerjee, R., and Antwi, J. (2017), Interest rate spread on bank profitability: The case of ghanaian banks, Journal of Accounting, Business and Finance Research, 1(1), 34-45.

Podsakoff, N. P., Whiting, S. W., Podsakoff, P. M., and Blume, B. D. (2009), Individual-and organizationallevel consequences of organizational citizenship behaviors: A meta-analysis, Journal of Applied Psychology, 94(1), 122-141.

Purba, S. (2009), Pengaruh budaya organisasi, modal intelektual, dan perilaku inovatif terhadap kinerja pemimpin jurusan di universitas negeri medan, Jurnal bisnis dan ekonomi, Kinerja, 13(02), 150-167.
Purmamisari, T. (2012), Antecedent OCB and Its Effect on Employee Performance, Dr. Dissertation, Brawijaya University, Malang, Indonesia.

Robbins, S. P. (2006), Perilaku Organisasi: Konsep, Kontroversi Dan Aplikasi, Edisi Kedua, Terjemahan Pudjaatmaka, Prenhallindo, Jakarta.

Sabri, T. B. H. and Sweis, K. M. (2015), The impact of the global financial crisis on the debt, liquidity, growth, and volume of companies in palestine stock exchange, Journal of Social Economics Research, 2(2), 31-37.

Sani, A., Ekowati, V. M., Wekke, I. S., and Idris, I. (2018), Respective contribution of entrepreneurial leadership through organizational citizenship behaviour in creating employee's performance, Academy of Entrepreneurship Journal, 24(4), 1-11.

Solimun (2012), Modeling Structural Equation Generalized Structured Component Analysis, $G S C A$, Diklat Multivariate Statistics Application: GSCA, Brawijaya University, Malang, Indonesia.

Suryanto, T., Haseeb, M., and Hartani, N. H. (2018), The correlates of developing green supply chain management practices: Firms level analysis in Malaysia, International Journal of Supply Chain Management, 7(5), 316-324.

Syafi'i, A. (2010), Social and Political Leadership. Leadership and Management Encyclopedia Muhammad SAW. The Super Leader Super Manager. Tazkia Publishing, Jakarta.

West, M. A. and Farr, J. L. (1990), Innovation and creativity at work: Psychological and organizational strategies, Wiley, Chichester.

Wijayanti, R. and Wajdi, F. (2012), Pengaruh kepemimpinan islami, motivasi dan kepuasan kerja terhadap kinerja karyawan dengan lama kerja sebagai variabel moderating, Daya Saing Jurnal Ekonomi Manajemen Sumber Daya, 13(2), 108-115 .

Yuliansyah, Y. (2015), Attributes influencing strategic alignment in the service sector: An indonesian banking sector case study, International Journal of Business, Economics and Management, 2(2), 34-48.

Zhang, Z. H. (2000), The effects of TQM implementation on overall business performance, In S. K. M. Ho and C. C. Leong (eds.), ISO 9000 \& TQM for 2000, 456-460, School of Business, Hongkong Baptist University, Hongkong. 